\title{
Effects of COVID-19 Pandemic on Small \& Middle-Income Economies (SMEs) in Developing Nations: A Case Study of Narok Town, Kenya
}

\author{
Morompi Ole Masago ${ }^{1}$, Moses Odhiambo Okombo ${ }^{2 *}$, Sambu Alice ${ }^{3}$, Kweingoti G Reuben ${ }^{3}$, Bakari Chaka ${ }^{4}$, \\ Bulitia Godrick $^{2}$, Ole Kelele Joshua ${ }^{3}$
}

\footnotetext{
${ }^{1}$ Department of Curriculum Instruction and Education Management, Maasai Mara University, Narok, KENYA

${ }^{2}$ Department of Economics Management, Maasai Mara University, Narok, KENYA

${ }^{3}$ Department of Social Studies, Religion and Community Development, Maasai Mara University, Narok, KENYA

${ }^{4}$ Department of Mathematics and Physical Sciences, Maasai Mara University, Narok, KENYA

*Corresponding Author: moses.okombo@gmail.com
}

Citation: Masago, M. O., Okombo, M. O., Alice, S., Reuben, K. G., Chaka, B., Godrick, B. and Joshua, O. K. (2020). Effects of COVID-19 Pandemic on Small \& Middle-Income Economies (SMEs) in Developing Nations: A Case Study of Narok Town, Kenya. Dutch Journal of Finance and Management, 4(2), em0067. https://doi.org/10.29333/djfm/9301

\section{ARTICLE INFO}

Received: 7 Aug. 2020

Accepted: 25 Sep. 2020

\begin{abstract}
The COVID-19 pandemic caught many Small and Middle-Income Enterprises (SMEs) unaware and unplanned. The pandemic led to restriction of several economic activities in Kenya; key amongst them transportation, tourism and education. The ripple effect of these restrictions caught up with SMEs, taunted to be a growing economic pillar in Kenya. This study purposed to analyze the exact effect of the pandemic on SMEs in Narok region, Kenya using various economic metrics. The findings were geared to furnish policy makers with the exact economic situation resulting from COVID-19. A case study research design was used with the help of questionnaires, interviews and observations. The researchers found out that most of the entrepreneurs were actually youthful. Commencement of SMEs was largely dependent on the political environment. Most of the SMEs in the region had begun between 2016 to 2018. The number of employees per SME had been effectively reduced to an average of 2 with their daily wages reduced from Ksh. 800 to 200. The pandemic reduced the supply of SMEs stock from other regions into Narok. 82.86\% of the SMEs were forced to obtain stock within the county itself. Both the supply of stock to SMEs and their corresponding demand by buyers were drastically reduced by $77.14 \%$ and $91.43 \%$ respectively. There was however no significant increment in the pricing of the products $(\mathrm{P}<0.05)$. The net profit margins of the SMEs reduced from in excess of Ksh. 20,000 to about Ksh. 5,000 per month. Other auxiliary services such as finance lenders, insurance and marketers were equally affected. About $54.45 \%$ of the SMEs were facing dissolution by their owners should the situation persist. In conclusion, the researchers found out that COVID-19 was more of an economic pandemic rather than a health pandemic in the study region. The authors recommend the national and county government to cushion the premises by waiving off some of their taxes.
\end{abstract}

Keywords: SMEs, COVID-19 pandemic, economic effects

\section{INTRODUCTION}

The government of Kenya defined Small and Middle-sized Enterprises (SMEs) as all those enterprises with employees ranging between 1 to 99 (Nation.co.ke, 2020). SMEs are a major revenue contributor to the Kenyan government (Wanjohi, 2010) because they ensure flow of money thus enabling the government to have various tax-collection points. The birth and growth of SMEs in Kenya spans back to pre-colonial era (Austin, 2010); where small and unlicensed economic activities went on with parties exchanging goods and services.
These practices not only promoted the 'rudimental' economies but also enhanced communal and inter-community peace and other social integrations.

Censoring of SMEs began in the neo-colonialism period. The key agenda of censoring these economies is to ensure maximum tax collection by the government. The current (Jubilee) government in Kenya has put a lot of emphasis on licensing all SMEs. This is because the sector has really grown to be a key government revenue source. Viffaconsult.co.ke (2019), indicated that this sector contributed 2.36 billion shillings in the 2018/2019 financial year. The researcher further indicated a positive turnover of the sector with about 
$30 \%$ contribution to the gross domestic product (GDP). SMEs were also attributed to creation of 846,000 new jobs $(83.6 \%$ of the jobs in informal sector) (Viffaconsult.co.ke, 2019). On the other hand, many citizens' livelihoods improved with provision of a good working environment by the government. For example, digitalization of tax filing minimized the time and paperwork that entrepreneurs spent in applying for the same (Gitaru, 2017). Other government services crucial in registration or control of these SMEs were also decentralized, alongside devolution of other government services. There was also harmonization of the sector players to provide a neutral trade platform. It is in this regard that SMEs have robustly grown in rural and marginalized towns such as Narok town, Kenya.

Narok town lies on the southern part of The Eastern Rift Valley, on the gate to the famous Maasai mara game reserve (Bartzke et al., 2018). The town is located between several communities in the region; including The Maasai (majority), The Gikuyu, The Kisii, The Kipsigis amongst other tribes in Kenya. Integration of these communities in the area renders it a metropolitan. These communities have all excelled in different economic activities i.e. Maasai (pastoralism and tourism), Gikuyu (agriculture and business), Kisii (agriculture and transportation) and Kipsigis (agriculture). Narok town thus became an epicentre of economic activities. The Great Maasai mara game reserve is also located in the county (Bartzke et al., 2018). Many local and foreign tourists visit the location leading to more flow of cash. Additionally, the town hosts several tertiary government institutes, key amongst them being Maasai mara university. These institutes service the town with occupants essential for the housing and construction industry. The institutions also pool government and other research grants into the town and provide technical labor through their graduates. All these factors coupled with the wonderful climate and nearness to Nairobi, Kenya's capital enables Narok town to have very vibrant SMEs.

The major economic activities of Narok town are agriculture, tourism \& hospitality and resources from government tertiary institutions (learn.e-Limu.org, 2020). With the gradual but sure encroachment of COVID-19 in Kenya, these activities were drastically halted. Forthwith, all government learning institutes were indefinitely closed on $15^{\text {th }}$ March, 2020 to protect learners and their teachers from acquiring the infections (Kenya.savethechildren.net, 2020). No sooner had this effect been realized than the government also banned foreign travel which is the major link to tourism in the country. Soon after, there was cessation of movement in several counties, including the capital (Nairobi), which is the epicentre of most economic activities in Kenya. The ban on social gatherings greatly affected the hospitality industry. These barriers slowly caught up with the agriculture industry whereby farm necessities such as seeds, fertilizer, farming equipment and laborers could not be easily transported. Regional tussles between Kenya and Tanzania over COVID-19 tests ensured the agricultural produce from the two regions delayed. With more tension brewing, the southern part of Narok (Trans-Mara) hosting The Maasai and Kipsigis engaged in communal wars which affected their working relationship.

All these factors caught up with SMEs in Narok town greatly affecting the industry. Several enterprises have since sent workers for compulsory leave while others have either been forcefully sacked or furloughed. The demand and supply chain have been extensively affected causing instabilities in the pricing of the commodities. Auxiliary services linked to SMEs including product promotion, insurance, banking, hospitality and transportation sectors are also in limbo. Uncertainties in epidemiology predictions of COVID-19 infections curve reduce planning by SMEs and most economic agreements have been replaced by a common phrase "wacha tutaona baada ya corona” (A Swahili phrase meaning "lets plan after the pandemic').

Despite all these irregularities, there is still no clear economic and scientific image of the exact position of SMEs in the town. It is pertinent to obtain this information, as it will be very crucial in re-opening of the sector. Pin-point data on the estimate (or exact) number of SMEs affected, how they have been affected and how they plan to mitigate these problems in future are still lacking. It is for this reasons that this study was carried out. The aim of the study was to furnish the affected SMEs, county and national governments, entrepreneurs and other sector key-players with information on the exact matter at hand for proper planning. This can save these players haphazard and uninformed decisions which can lead to wastage of money and critical time required for re-opening up the sector. The researchers also believe that the findings herein obtained are a true reflection of many other regions in Kenya, Africa and other low-income nations.

\section{RESEARCH METHODOLOGY}

\section{Design of Study}

A case study research design was followed, with the study being conducted in the month of June, 2020. The period was arrived at as having been estimated as the most economicallyaffected month. The criterion of argument was that it was the month just before uplifting of the cessation of movement in and out of Nairobi capital; after which the economy of the country was expected to better. The study was conducted in various wards of Narok county (coordinates $1.0918^{\circ} \mathrm{S}$, $35.8498^{\circ} \mathrm{E}$ ) as outlined in Figure 1. The wards were chosen based on population and economic growth (Kenya National Bureau of Statistics, 2019). The wards included Narok Town, Mara, Loita, Naikarra and Uraololung'a. Data was collected using questionnaires (see Appendix 1). Qualitative and descriptive analysis was conducted due to the nature of the research at hand. The target population was owners of various SMEs in the town with different industrial background spanning from tourism and hospitality, agriculture, transportation, communication, estates and development (including housing), entertainment to finance and banking amongst others.

\section{Sampling Techniques}

Despite having so many participants of SME sector in the county, it was unrealistic to get the respondents of all the members due to time and budget. Simple random sampling was therefore more suitable for the study. The method was also preferred for its ability to sample a small representative group from a bigger population with limited bias. Any respondent 


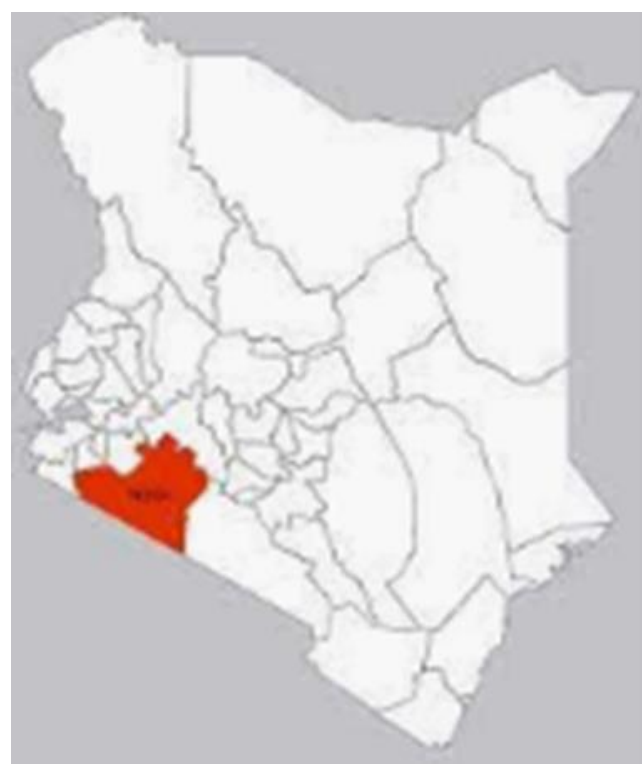

(a)

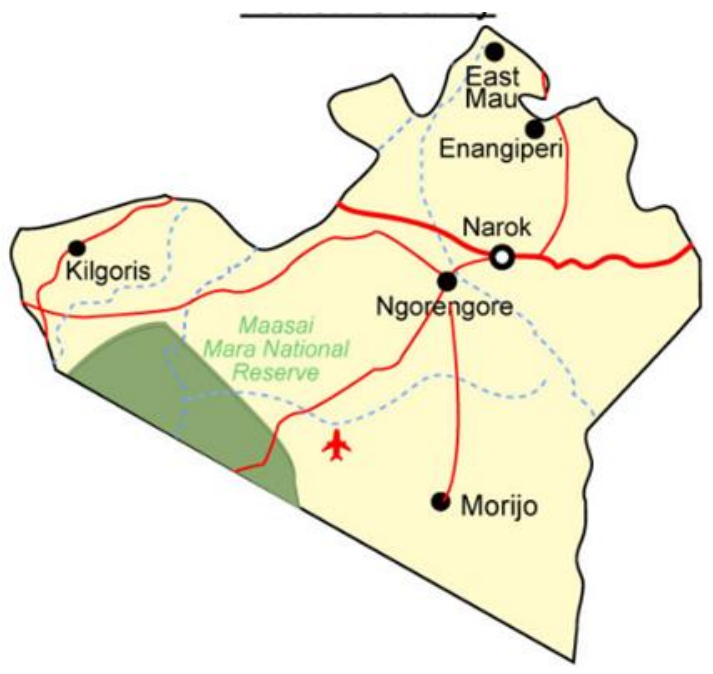

(b)

Figure 1. The study location. The study was conducted in Narok county in Kenya (a) in Narok town which is the major town of the county (b)

Source: learn.e-limu.org. (2020) (Figure 1a) learn.e-limu.org. (2020) (Figure 1b)

could be taken from the main target population with equal probability. The researchers targeted a variety of enterprises in the town to get a true reflection of the situation.

\section{Sample Size}

The target population of SMEs in Narok town was quite large. This is because the town is densely populated with people and economic activities. The target population could not be wholly analyzed and was therefore reduced to 80 samples. The sample size was arrived at from Slovin's formulae (Statisticshowto.com, 2020) outlined in Eq. 1.

$$
n=\frac{N}{1+N\left(e^{2}\right)}
$$

Where, n-sample size, N-population size, e- Error term (5\%) based on $95 \%$ confidence interval

The samples were spread out across the various wards (5) in the town. Therefore, each ward had 16 samples taken.

\section{Research Questionnaires, Interviews and Observation Guides Used}

The study involved use of questionnaires guides, interviews guides and observation. Questionnaires were given out to literate respondents. The questionnaires were unstructured and had both open ended and closed research questions. The questionnaires were divided into 3 main sections i.e respondents biodata section, information on the enterprises and a section involving effects of COVID-19 pandemic on the SMEs. The researchers guided the respondents on the areas needing interpretation or any other assistance. For illiterate respondents, the researchers took the respondents through the study via interviews guides. The structure and content of the guides was similar to that of the questionnaires. Both the questionnaires and interview guides were designated to collect the same type of data. Observations were made to assess some of the situations that could easily be noticed. There was no clear structure or number of research items in an observation guide but rather researchers' opinion on notable features of respondents and the SMEs.

\section{Validity and Reliability of the Research Guides Used}

Questionnaires were quite reliable since they were easy to administer and encouraged confidentiality thus, reducing biasness. Interviews enabled the use of open-ended questions that aided in acquiring reliable findings and more detailed answers. Both were subjected to the test-retest reliability method to check for their consistency in results after a duration of 10 days. A group of 10 respondents (volunteers) was used. There was a similarity index of $69 \%$ in the results at the two instances of testing. Observation also ensured gathering of reliable data. The 10 respondents were also assigned with the same task and a $58 \%$ similarity index observed. A face validity of the research guides was conducted by 5 volunteers. A pilot study was then conducted to determine the validity of the data collection instruments used. Each of the 50 initial distinct research questions in the questionnaire guide (excluding bio-data section) was assigned to 3 different respondents. In total, there were 150 respondents (volunteers). The data was then debugged and the minimum and maximum values recorded. After a critical analysis check, 5 questions were found to be confusing and leading. These questions were plucked out. The ultimate validity score was thus $45 / 50$ (90\%) and the outcomes were found to strongly favor the use of these research guides.

\section{Data Analysis}

The data collected was analyzed and presented using descriptive statistics. The data collected was analyzed using Ms Excel (2016). For the significance levels, a confidence level of $95 \%$ was used. 


\section{RESULTS AND DISCUSSIONS}

\section{Biodata of SMEs Owners}

Most of the SMEs entrepreneurs in Narok town were within the active population bracket (below 58 years). Majority (36.11\%) of the entrepreneurs were actually in their youthful stages of between 21 and 35 years. Only $2.78 \%$ of the entrepreneurs were below 20 years of age while those between 31-40 years and $41-50$ years amounted to $25 \%$ for each of the two age brackets. Cumulatively, more than $65 \%$ of the entrepreneurs were below 40 years. This implies that the youth in the region have taken up to business vis-à-vis the convectional economic activities in the region. This can be attributed to their dissatisfaction with blue-collar jobs. Most youths are known to prefer informal jobs in urban centres (such as SMEs), rather than in rural areas (Hope, 2012). Majority of the youth have completed high school or tertiary education thus find business to be a softer landing point after having failed to settle for white-collar jobs. The national government of Kenya (GoK) has also been giving incentives and business loans to organized youth groups (Sikenyi, 2017; GoK, 2008). This move has led to influx into business by the youth in Narok. The gender ratio of entrepreneurs was even (i.e. 1:1). This is quite interesting given the male chauvinistic behavior of the majority of Narok residents (Maasai). The increased number of female entrepreneurs is attributed to continual campaigns against male chauvinism. $62.86 \%$ of the entrepreneurs had begun families but with a single partner and less than 2 children while $37.14 \%$ of them were still single.

\section{Background Information Concerning the SMEs}

Majority (75.76\%) of the SMEs were owned by sole proprietors. Most of them acknowledged little capital required and independence of decision making in running the SMEs as the main reasons for deciding to run the firms alone. The sole proprietors claimed that it is tedious and quite insecure to manage an SME with other partners. It was thus not surprising to find that only $6.06 \%$ of the SMEs were of a partnership business unit. This form of SMEs was dreaded for strained working relationships amongst the partners (Silva, 2016); especially after the SMEs started realizing profits. Only 3.03\% of the SMEs were owned by a SACCO while $15.15 \%$ of the SMEs were registered companies. There has been reduced paperwork concerning company registration in Kenya. This has led to an increase in the number of companies in the region.

Since most of the SMEs were in sole proprietorship, capital used for their registration was mainly from offsetting individual assets (45.45\%) and savings (9.09\%). This mode of capital is quite easy especially for single individuals. The source of capital is actually a key factor to the nature of SME to engage in. $18.18 \%$ of the enterprises obtained capital from loans and borrowing. Majority of these members belonged to youth groups which easily acquire government loans through their county or constituency representatives. This process has been simplified by a national government program called as Uwezo Fund; which is specifically geared towards providing youths with business loans and other incentives (Kilele et al., 2015 , p.10). However, the process is sometimes politically manipulated and have limited the number of successful applicants. $18.18 \%$ of the SMEs obtained their initial capital from ploughing back profits earned from previous businesses. This scheme ensures the longevity of different types of business by an individual. 9.09\% of the SMEs capital was obtained from members shares. This method was specifically tailored for the SACCO, company and partnerships whereby shares and dividends exist.

A good number of the SMEs were registered over the last 5 years. There was a decline in number of SMEs registered between the year 2010 to 2013. This can be attributed to change in government regimes and the affiliated political insecurities. Narok region has been a hotbed of political rivalries and conflicts (Boone et at., 2019) owing to its metropolitan nature. There were political clashes in the region in 1997 and 2007 (following national general election polls). The post-election chaos created is usually tribal and SMEs owners not belonging to some tribes (depending on their political alignment) are chased away. In 2007, business enterprises belonging to the 'outcast' communities were torched. These political instabilities greatly affect investments in SMEs when national polls near. This was the main reason for the drop in number of registered SMEs between 2010 (17.07\%) and 2013 (7.32\%). Thereafter, the number of SMEs gradually increased to a high-notch of $29.27 \%$ between 2017 2018. In the general election held in 2017, majority of Narok residents belonged to the same political alignment therefore the business environment was calm. A good number of SMEs were also commenced in 2019. However, due to COVID-19 unrest at the beginning of 2020, SMEs registration came to a dead halt. This led to the drastic reduction in SMEs to 14.63\% for the 2019-2020 range. Closure of other key activities due to the pandemic greatly minimized the number of SMEs registered. Majority of the residents prefer to secure other primary commodities such as food, rent and health care instead of engaging in business. The trend of number of registered SMEs in Narok town is illustrated in Figure 2.

All the SMEs were found to have books of account necessary to track their business transactions. Use of cash books and computerized accounting programs were the most popular means (33.33\% each). These methods were preferred for their simplicity of use even to entrepreneurs with little accounting knowledge. Computerized accounting programs also eliminate paperwork while ensuring more durability of business records (Stausberg et al., 2003). 13.89\% of the SMEs used ledgers. These books of account were mainly found in the companies and SACCOs where there were more accounting elites. $13.89 \%$ of the entrepreneurs used mobile banking records (in this case M-Pesa) as a means to track their business transactions. The entrepreneurs argued that they had a lot of faith with this system because several of their clients transacted using mobile money. This is an emerging player in the sector and is likely to grow further due to limitations of use of cash (Mbiti and Weil, 2013) in the COVID-19 era. Use of cash is associated with contact which is the primary mode of transmission of corona virus, responsible for COVID-19 disease.

\section{Effect of COVID-19 on Number of SMEs Employees}

Majority of the SMEs had two or less employees before (31.43\%) and after (57.14\%) COVID-19 pandemic. This is 


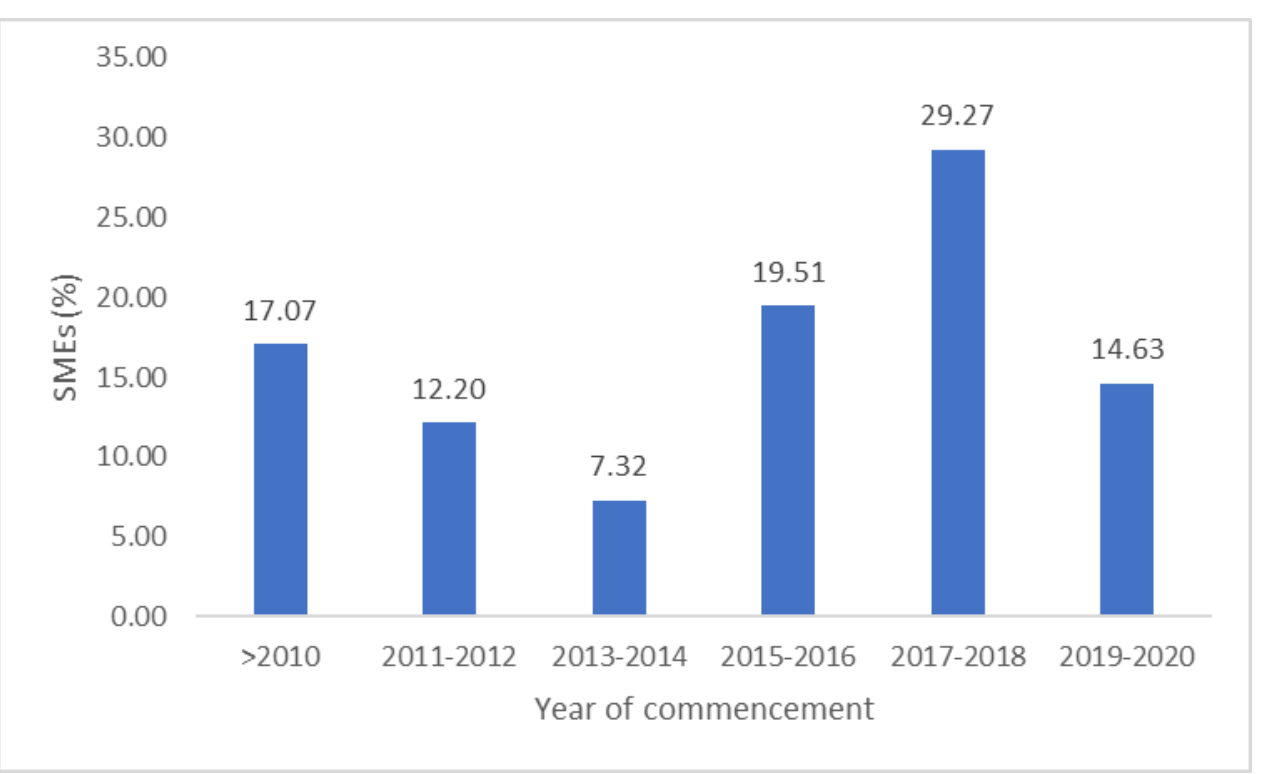

Figure 2. The period of SMEs commencement in Narok town over the past 10 years

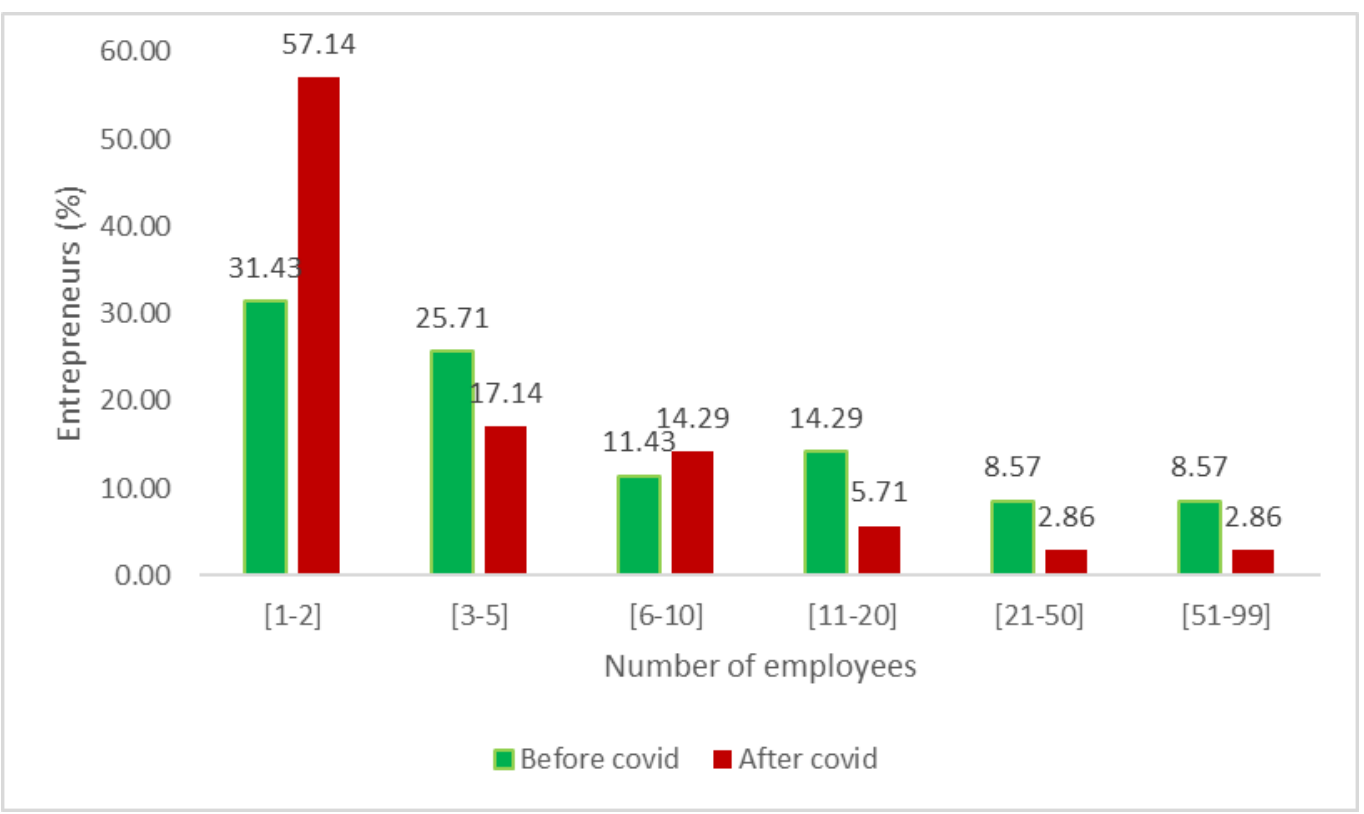

Figure 3. Effect of COVID-19 pandemic on the number of SMEs employees in Narok

attributed to the nature of the enterprise (sole proprietorships) which do not require a large workforce. SMEs with more workforce were forced to reduce the number by either giving compulsory partially-paid or unpaid leaves or terminating the contracts of some of the employees. Some of the SMEs decided to engage family members in the enterprise (since schools had closed without any probability of resumption). Other employees decided to quit and engage in other activities after their salaries were slashed. All these factors led to a reduction in the number of employees in the SMEs (Figure 3). SMEs with two and below workers increased from $31.43 \%$ to $57.14 \%$. This number is likely to increase further if the pandemic is to persist. Figure 3 illustrates how the number of employees in SMEs have been affected by COVID-19 pandemic.

The cumulative number of SMEs with many employees drastically reduced as that with few employees increased. $8.57 \%$ of the SMEs had between 21 to 50 employees and 51 to 99 employees before the pandemic. The number was drastically brought down to $2.86 \%$. This indicates a significant number of jobs lost as a result of the pandemic $(\mathrm{P}>0.05)$. This is however a global scenario (Nicola et al., 2020). 65\% of the entrepreneurs admitted to furlough or lay off more workers should the pandemic persist.

\section{Effect of COVID-19 Pandemic on Employees' Wages in SMEs}

There was a significant reduction in employees' wages resulting from the pandemic $(\mathrm{P}>0.05)$. Majority of the employees earned in excess of Ksh. 600 before the pandemic (over $55 \%$ of the employees). Only $2.86 \%$ of the employees earned less than 200 shillings while $20 \%$ earned between 200 and 400 shillings daily. Reduction in business activities with closure of the economy due to the pandemic consequently led to reduced profit margins and by extension lower wages. The number of employees earning in excess of 600 shillings daily have gradually reduced $5.72 \%$ from $55 \%$. The majority of these workers now earn below 600 shillings with $37.14 \%$ of them 


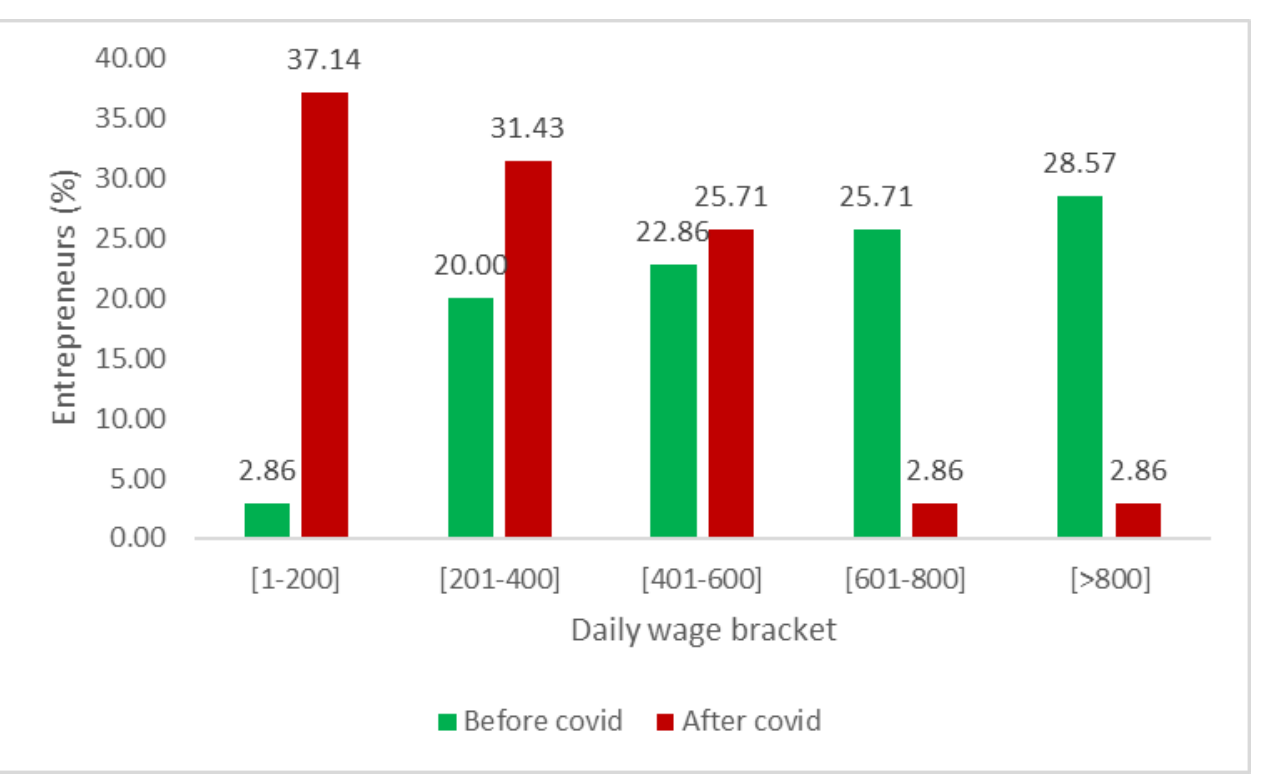

Figure 4. Change in the wages of SMEs employees in Narok due to COVID-19 pandemic

earning 200 shillings and below. The employees earning between 200 and 400 shillings drastically increased from $20 \%$ to $31.43 \%$ while that between 400 and 600 shillings increased from $22.86 \%$ to $25.71 \%$. This has rendered SMEs quite unprofitable leading to closure of some of the entities. Many SMEs in the region are actually closed down as some entrepreneurs prefer to close and engage in other activities rather than make lower profits. Those still operating believe that things will soon stabilize and get back to normal wages. Others believed that closing down the SMEs would result to starting up from ground zero. This is a quite dreadful but real situation with many other enterprises that have had to start from scratch after closure for a long time (Smith et al., 2019, p.10080). They therefore feel that it is better for the enterprises to survive through the hard times as they take paycuts hoping that things soon stabilize. The reduction in employees' wages before and after the pandemic is illustrated in Figure 4.

The drastic reduction in employees' wages is a good indicator of possible SMEs dissolution (Nicola et al., 2020). Actually, majority of the entrepreneurs confirmed that should the situation persist, within a few months over $50 \%$ of the enterprises would shut down. This has a very negative toll on the revenue collected by the government.

\section{Effect of the Pandemic on the Source of SMEs Products}

About 54.29\% of SMEs in Narok region were forced to change their source of business materials after the pandemic. $45.71 \%$ of SMEs obtained their raw materials from Narok region before the pandemic was pronounced in Kenya. Most of these SMEs were retail shops and other firms dealing with agricultural produce. Majority of them were sole proprietors due to the scales of operations involved. This number (of SMEs obtaining their supplies from Narok) sharply increased to $82.86 \%$ within 4 months. This is partially due to limitation of movement from various COVID-19 hotbeds in the nation. Some of these SMEs relied on products from Nairobi, Mombasa or overseas whose transportation was greatly limited. The few traders who brought raw materials from Nairobi and Mombasa increased the price of their commodities to cater for the extra
Table 1. Effect of COVID-19 pandemic on source of SMEs supply of materials

\begin{tabular}{ccc}
\hline \multirow{2}{*}{ Source of materials } & \multicolumn{2}{c}{ SMEs (\%) } \\
\cline { 2 - 3 } & $\begin{array}{c}\text { Before COVID-19 } \\
\text { pandemic }\end{array}$ & $\begin{array}{c}\text { After COVID-19 } \\
\text { pandemic }\end{array}$ \\
\hline Narok & 45.71 & 82.86 \\
\hline Nairobi & 37.14 & 17.14 \\
\hline Nakuru & 8.57 & 0.00 \\
\hline Tanzania & 8.57 & 0.00 \\
\hline
\end{tabular}

costs incurred while transporting them. Out of the $37.14 \%$ SMEs who wholly relied on Nairobi for their supplies, only $17.14 \%$ of them still obtained the supplies from this source after the pandemic. These few remaining ones were mostly wholesalers. They however confirmed to increasing the prices of the commodities to cater for the tedious transportation of supplies. Not only were they forced to secure COVID-19 free certificates for their drivers and assistants but also had to increase 'take-away bribes' for traffic officers. The drivers admitted that the bribes being given to traffic officers had increased in order to be cleared quickly. Briberies and other social irresponsibility's are known to increase during uncertain times such as in pandemics (Sharma et al., 2020). Some of the SMEs obtained their supplies from Nakuru and Tanzania (both $8.57 \%$ ) but were forced to seek these supplies locally after the pandemic. This was informed by the increased cost of transportation of the materials. There were a lot of delays at the Kenya-Tanzania border points with compulsory tests being taken there. These delays made perishable agricultural products from Tanzania to spoil causing massive losses. To avoid this situation, some of the SMEs opted to cease the trade until the situation is resolved. Others opted to look for the supplies locally (in Narok). Therefore, the number of SMEs relying on Narok county for supplies increased significantly ( $\mathrm{P}$ $>0.05$ ) as illustrated in Table 1.

\section{Effect on Demand and Supply of Products}

With the source of materials supply in question and the money-spending capacity of Narok residents in limbo, it was rather obvious that demand and supply curves would be 
affected. As in other pandemics, priority for spending was given to basic items such as food and health care (Madhav et al., 2017). There was also demographic movement towards the rural areas as residents anticipated for tougher times ahead and sought refuge in rural areas. This was further worsened by the fear of the buyers to visit SMEs where social distancing rules might not be fully met. $77.14 \%$ of the entrepreneurs reduced the supply of their products willingly or unwillingly. Willing reduction was informed by reduced profit margins arising from shift of demand curve with the prevailing conditions. Unwilling reduction in supply of their products was determined by reduced transportation and increase in prices of the products. The reduction in supply of the products is accompanied by their increase in cost (for $54.28 \%$ of the enterprises). $22.86 \%$ of the entrepreneurs were still able to acquire the products with the same price as before. Out of these entrepreneurs, about $17.14 \%$ were not affected by the supply of raw materials from their sources. Some (5.71\%) of the local SMEs who relied on agricultural produce from around Narok region actually had the products in surplus. This phenomenon resulted from farmers who relied on far away markets such as from Nairobi, Nakuru or Tanzania having to sell their produces locally due to limitation of movement. The

Demand of SMEs products was significantly reduced by the pandemic $(P>0.05)$. 91.43\% of the entrepreneurs had the demand of their products reduced. Several factors can be attributed to this reduction in demand. Demographic movement away from Narok, especially for SMEs around the tertiary institutes such as Maasai mara university whose main residents are students greatly affected the demand. Demography is a key economic parameter and any change in demography has economic implications (Heuveline, 2001). Some other enterprises rely on presence of the students; directly or indirectly and were equally affected. Some of the residents also considered other (rural) areas to be safer than Narok (in terms of COVID-19 disease infection). A good number of the residents also rely on tourists, especially as it was approaching summer whereby many tourists flock Narok county. These residents had their source of income cut and thus their buying capacity was also cut. Priority of spending the meagre funds available was taken towards basic services. Some of the residents also feared congregating in shopping centres and minimized buying. Buying was only made when necessary. Only $2.86 \%$ of the SMEs had an increase in demand of their products. $5.71 \%$ of the SMEs did not have the demand of their products affected by the pandemic. The high decline in demand of products affected pricing of commodities in different ways. $42.86 \%$ of the SMEs reduced the price of their commodities in order to lure more clients while maintaining their previous ones. $28.57 \%$ of the SMEs did not change the prices of their commodities while $28.57 \%$ increased the prices to cover up for the losses made during purchasing. Balancing the buy-and-sell dynamics in such insecure and uncertain period was very disturbing to most of the entrepreneurs. Many risks are usually taken within these circumstances and understanding the perception of clients is very pertinent (Zauner et al., 2015).
Table 2. Effect of COVID-19 pandemic on demand and supply of products

\begin{tabular}{ccc}
\hline \multirow{2}{*}{\begin{tabular}{c} 
Change in supply or $\begin{array}{c}\text { demand } \\
\end{array}$ \\
\cline { 2 - 3 }
\end{tabular}} & \multicolumn{2}{c}{ Demand and supply parameter } \\
\cline { 2 - 3 } & \multicolumn{2}{c}{ Supply of products (\%) } \\
\hline Quantity & Price \\
\hline No change & 5.71 & 54.28 \\
\hline Decreased & 17.14 & 22.86 \\
\hline & 77.14 & 22.86 \\
\hline & Demand of products (\%) \\
\hline Increased & Quantity & Price \\
\hline No change & 2.86 & 28.57 \\
\hline Decreased & 5.71 & 28.57 \\
\hline
\end{tabular}

low number of increased supply of products (5.71\%) against that of reduced supply (77.14\%) implies that Narok SMEs heavily rely on other regions for business commodities. This is because the region has very few processing and manufacturing firms. With the relatively little (5.71\%) increment in surplus of products, about $22.86 \%$ of the SMEs could now acquire their raw materials at a cheaper place. The dynamics of supply and demand of products after COVID-19 pandemic are illustrated in Table 2.

\section{Effects on the Profits Made by SMEs}

The turbulent demand and supply challenges faced by the entrepreneurs were manifested in their profits. The profit margins of the SMEs reduced in a free-flow manner; from excess of 20,000 to around 5,000 shillings per month. Prior to the pandemic, no entrepreneur made a profit of less than 500 shillings a month while only $2.86 \%$ of the entrepreneurs made less than 10,000 shillings profit a month. All the other entrepreneurs made more than this with the majority (60\%) making profits in excess of 20,000 shillings a month. The high cost of supplies coupled with their scarcity and lower spending power of the buyers all led to reduced profit margins. Some of the entrepreneurs become panic-stricken with prevailing conditions (such as the pandemic crisis) leading to business mistakes (Barry, 2009). The government was also quite reluctant in cushioning businesses from taxes and other liabilities. Some of the low profit margins were realized by sacrifices made by the entrepreneurs to sustain their employees' normal wages. The reduction in profit margins before and after the pandemic is illustrated in Figure 5 .

After the pandemic, there was a marginal shift in profits from the higher side (above 20,000 shillings) to the lower one (less than 5,000 shillings per month). About $51.43 \%$ of the entrepreneurs now had profits of less than 5,000 shillings per month. This value, they said was only meant to sustain their businesses through the turbulent times. Most were optimistic of better rewards in the future compared to their colleagues who had totally shut down. $54.45 \%$ of the entrepreneurs contemplated shutting down their enterprises altogether should the situation persist. 


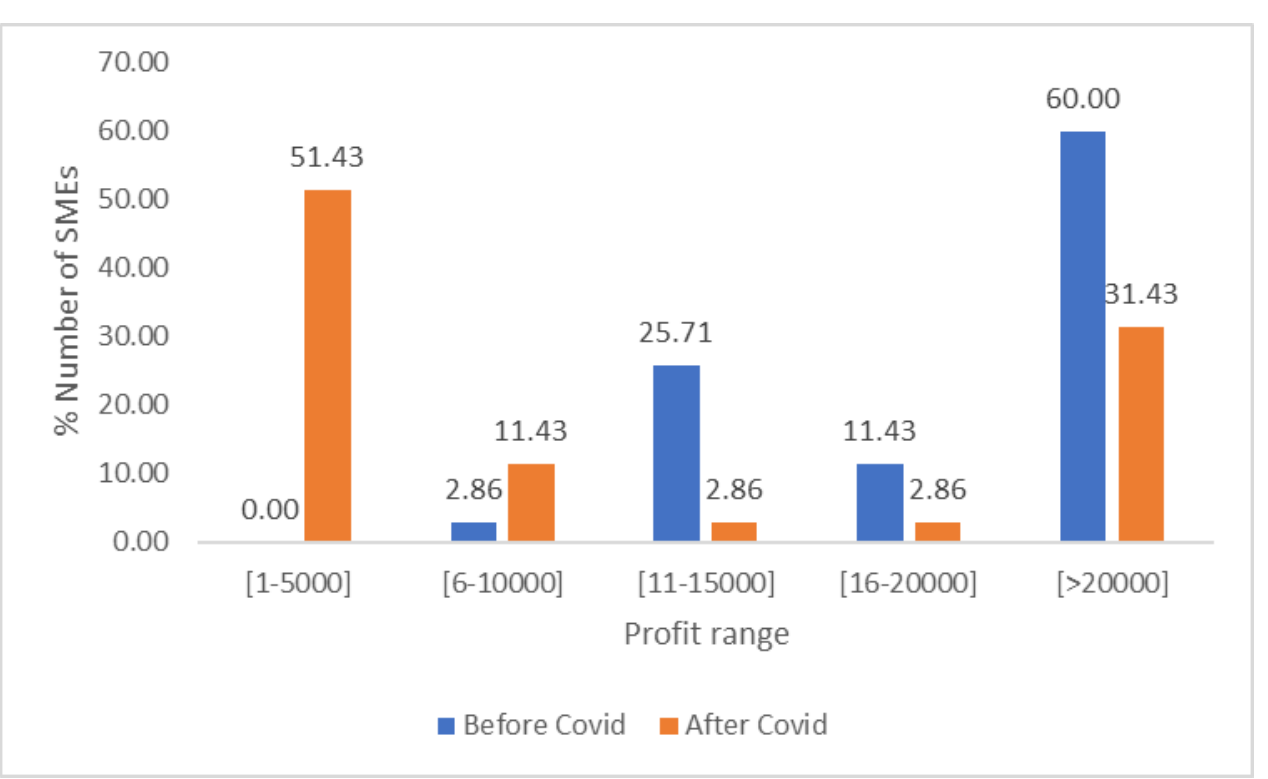

Figure 5. Effect of COVID-19 pandemic on profit margins of SMEs in Narok

\section{Effects on Auxiliary Services Linked to SMEs}

Some of the SMEs (28.57\%) still had financial loans to clear even with the prevailing conditions. The owners of these SMEs confirmed that most financial lenders had been kind enough to extend the pay-back period. Other financial lenders had suspended the interest rates until business was back to normal. This played a role in the SMEs sustainability. No entrepreneur with financial loans admitted to being able to clear it this year. $40 \%$ of the entrepreneurs with loans confirmed to be in a position to clear the loan within 3 years while $20 \%$ could clear it within 5 years. However, another $40 \%$ were not certain if they could clear it in less than 5 years and required more time to do so. These delays in settling financial loans greatly affect the economy as the lenders become more stringent in their terms. Interest caps and other policies have previously been enforced to regulate the financial lenders with mixed economic effects (Safavian and Zia, 2018). For example, the Kenyan government imposed a cap on the interest rate of financial lenders in the territory for the financial year beginning 2018/2019 (Safavian and Zia, 2018). This cap was however revised less than two years later as it had greatly limited the liquidity of money in the country. The newer more friendlier terms were about to start taking place just before the pandemic begun.

About $68.57 \%$ of the enterprises had been insured before the pandemic struck. Very few of the insurance policies were against business interruptions; while non was specifically against interruption by a pandemic. The entrepreneurs were thus completely caught unawares. $85.71 \%$ of the SMEs had engaged in different types of product promotion. Use of social media for marketing was alleged to be the cheapest and simplest method. A few of the entrepreneurs used billboards while others had engaged in other forms of print media, television and radio. The entrepreneurs indicated that marketing strategies were no longer working since most buyers had preset minds on types of commodities to buy. This was informed by the tough economic crisis and thus buyers prioritized only the basics required.

\section{CONCLUSIONS}

Most of the entrepreneurs in Narok town were found to be quite youthful. Commencement of SMEs largely depended on the political environment present; with majority of the SMEs being registered between 2017 and 2018. COVID-19 pandemic had effectively reduced the number of active employees in SMEs to an average of 1-2 employees. Their wages were also significantly reduced from about Ksh. 800 to 200 per day ( $\mathrm{P}>$ $0.05)$. The pandemic also affected the source of SMEs stock with $82.86 \%$ of the enterprises now obtaining their stock from Narok. Both the supply of stock for SMEs and the corresponding demand of the products by buyers had drastically reduced by $72.14 \%$ and $91.43 \%$ respectively. There was no significant change in the retail price of the commodities $(\mathrm{P}<0.05)$. Profit margins reduced from excesses of 20,000 shillings to 5,000 shillings per month. No entrepreneur had insured their SME against business interruption by pandemic. $54.45 \%$ of the entrepreneurs contemplated shutting down the premises should the situation persist.

\section{RECOMMENDATIONS}

The national government should actualize their promises of cushioning SMEs in Kenya. The taxes paid to the county government should be waived since the premises have really been hit by the pandemic.

\section{ACKNOWLEDGEMENTS}

The authors are grateful to all the respondents who assisted to participate in the study. 


\section{REFERENCES}

Austin, G. (2010). African Economic Development and Colonial Legacies, International Development Policy, Revue internationale de politique de développement, 1, 78. https://doi.org/10.4000/poldev.78

Barry, J. (2009). Pandemics: avoiding the mistakes of 1918. Nature 459, 324-325. https://doi.org/10.1038/459324a

Bartzke, G. S., Ogutu, J. O., Mukhopadhyay, S., Mtui, D., Dublin, H. T. and Piepho, H. P. (2018). Rainfall trends and variation in the Maasai Mara ecosystem and their implications for animal population and biodiversity dynamics. PloS one, 13(9), e0202814. https://doi.org/10.1371/journal.pone.0202814

Boone, C., Alex, D., Ambreena, M., Catherine, W. G., Seth, O., James, K. O., Achiba, G. and Jacqueline, M. K. (2019). Land law reform in Kenya: Devolution, veto players, and the limits of an institutional fix. African Affairs, 118(471), 15237, https://doi.org/10.1093/afraf/ady053

Gitaru, K. (2017). The Effect of Taxpayer Education on Tax Compliance in Kenya. (a case study of SME's in Nairobi Central Business District). MPRA Paper No. 80344, posted 27 Jul 2017 15:43 UTC. Available at: https://mpra.ub.unimuenchen.de/80344/

GoK (Government of Kenya) (2008). Youth Enterprise Development Fund: Status Report, Nairobi: Ministry of Youth Affairs. Available at http://www.youthfund.go.ke/ (Accessed: 23 July 2020).

Heuveline, P. (2001). Demographic pressure, economic development, and social engineering: An assessment of fertility declines in the second half of the twentieth century. Population research and policy review, 20(5), 365396. https://doi.org/10.1023/A:1013339124837

Hope, K. R. S. (2012) Engaging the youth in Kenya: empowerment, education, and employment. International Journal of Adolescence and Youth, 17(4), 221-236. https://doi.org/10.1080/02673843.2012.657657

Kenya National Bureau of Statistics (2019). 2019 Kenya Population and Housing Census Volume I: Population by County and Sub-County. Available at: https://www.knbs. or.ke/?wpdmpro=2019-kenya-population-and-housingcensus-volume-i-population-by-county-and-sub-county (Accessed: 23 July 2020).

Kenya.savethechildren.net, (2020). Save the children/Our response to COVID-19 in Kenya. Available at: https://kenya.savethechildren.net/what-we-do/ourresponse-COVID-19 (Accessed: 23 July 2020).

Kilele, K. A., Nduruhu, D. and Kimani, M. (2015). Determinants of Group Loans Uptake at The Youth Enterprise Development Fund a Survey of Nakuru West Constituency, Kenya. International Journal of Commerce, Economics and Management, 3, 10. Available at: https://www.researchgate .net/deref/http\%3A\%2F\%2Fijecm.co.uk\%2F

Learn.e-limu.org (2020). Counties in Kenya. Available at: http://learn.e-limu.org/topic/view/?c=468\&t=1518 (Accessed: 23 July 2020).
learn.e-Limu.org. (2020). eLimu/Resources and economic activities. Available at: http://learn.e-limu.org/topic/ view/?c=48\&t=280 (Accessed: 20 July 2020).

Madhav, N., Oppenheim, B. and Gallivan, M. (2017). Pandemics: Risks, Impacts, and Mitigation. Disease Control Priorities: Improving Health and Reducing Poverty. 3rd edition. Washington (DC): The International Bank for Reconstruction and Development / The World Bank; 2017 Nov 27. Chapter 17. https://doi.org/10.1596/ 978-1-4648-0527-1_ch17

Mbiti, I. and Weil, D. N. (2013). The Home Economics of EMoney: Velocity, Cash Management, and Discount Rates of M-Pesa Users. The American economic review, 103(3), 369374. https://doi.org/10.1257/aer.103.3.369

Nation.co.ke (2020). SMEs Driving Kenyan Economy, Nation Kenya. Available at: https:/www.nation.co.ke/kenya/ news/politics/smes-driving-kenya-s-economy-253732 (Accessed: 20 July 2020).

Nicola, M., Alsafi, Z., Sohrabi, C., Kerwan, A., Al-Jabir, A., Iosifidis, C., Agha, M., \& Agha, R. (2020). The socioeconomic implications of the coronavirus pandemic (COVID-19): A review. International journal of surgery (London, England), 78, 185-193. https://doi.org/10.1016/ j.ijsu.2020.04.018

Safavian, M. and Zia, B. (2018). The Impact of Interest Rate Caps on the Financial Sector: Evidence from Commercial Banks in Kenya. Policy Research Working Paper;No. 8393. World Bank, Washington, DC. (c) World Bank. https://doi.org/10.1596/1813-9450-8393

Sharma, P., Leung, T. Y., Kingshott, R., Davcik, N. S. and Cardinali, S. (2020). Managing uncertainty during a global pandemic: An international business perspective. Journal of business research, 116, 188-192. https://doi.org/ 10.1016/j.jbusres.2020.05.026

Sikenyi, M. (2017). Does Kenya's Youth Enterprise Development Fund Serve Young People? IDS Transforming Business Knowledge, 48(3). https://doi.org/10.19088/19682017.131

Silva, G., Dacorso, A. L. R., Costa, V. B. and Serio, L. C. D. (2016). Relationships and Partnerships in Small Companies: Strengthening the Business through External Agents. BAR - Brazilian Administration Review, 13(1), 118. https://doi.org/10.1590/1807-7692barnaahead0116

Smith, K. M., Machalaba, C. C., Seifman, R., Feferholtz, Y., \& Karesh, W. B. (2019). Infectious disease and economics: The case for considering multi-sectoral impacts. One health (Amsterdam, Netherlands), 7, 100080. https://doi.org/ 10.1016/j.onehlt.2018.100080

Statisticshowto.com (2020). Research Assignments - Slovin's formulae: What is it and When do I use it - Statistics How to. Available at: https://www.statisticshowto.com/how-touse-slovins-formula/ (Accessed: 23 July 2020).

Stausberg, J., Koch, D., Ingenerf, J. and Betzler, M. (2003). Comparing paper-based with electronic patient records: lessons learned during a study on diagnosis and procedure codes. Journal of the American Medical Informatics Association: JAMIA, 10(5), 470-477. https://doi.org/10.1197 /jamia.M1290 
Viffaconsult.co.ke (2019). SMEs Performance Index 2019. Available at: http://viffaconsult.co.ke/wp-content/uploads /2019/12/KENYA-SME-PERFORMANCE-INDEX-2019.pdf (Accessed: 23 July 2020).

Wanjohi, A. M. (2010). SMEs Policy in Kenya: Issues and Efforts in Progress. KENPRO Publications. Available at: http://www.kenpro.org/papers/sme-policy-in-kenya.html
Zauner, A., Monika, K. and Isabella, H. (2015) Customer perceived value-Conceptualization and avenues for future research. Cogent Psychology, 2(1). https://doi.org/ $10.1080 / 23311908.2015 .1061782$

\section{APPENDIX 1}

\section{Effects of COVID-19 Pandemic on Small \& Middle-Income Economies (SMEs) in Narok Town, Kenya}

Hello. My name is . I am a researcher from Maasai Mara University. Together with my team, I am interested with knowing how the COVID-19 pandemic have affected your enterprise. Kindly feel free to collaborate with us as we seek to help reach out to the necessary authorities to air your concerns.

Date:

Section A: DEMOGRAPHIC INFORMATION

Sign:

1. Name:

2. Age:

3. Gender: a) [Male]; b) [Female] (Please tick ( $\sqrt{ })$ where appropriate)

4. Marital status: a) [Single] b) [Married] c) [Divorced] d) [Bereaved]

5. Family size: a) Number of wives/husbands [ ]; b) Children [ ]

6. County of background:

Section B: BUSINESS BACKGROUND

1. What is the name of your business?

2. Is it legally registered?

b) If NO, Why?

3. What type of business enterprise is it? [Sole proprietorship] [Partnership] [SACCO] [Company]

4. When did it begin operations?

5. What was its initial source of capital?

6. What is its location? a) Ward: b) Estate:

7. At what time of the day do you; a) Open business? b) Close business?

8. Which days of the week do you operate?

9. Do you keep records of business transactions?

b) If YES, How? i) [Cash book] ii) [Ledger] iii) [Receipt book] iv) [Other]

\section{Section C: EFFECTS OF BUSINESS RESULTING FROM COVID-19 PANDEMIC}

1. a) How many employees did the business have;

$$
\begin{aligned}
& \text { i) before the pandemic? } \\
& \text { ii) after the pandemic? }
\end{aligned}
$$

b) What skills/qualifications did you consider for employment;

$$
\text { i) before the pandemic? }
$$

ii) after the pandemic?

c) What was your average salary/daily wages of your employees

$$
\begin{aligned}
& \text { i) before pandemic? } \\
& \text { ii) after pandemic? }
\end{aligned}
$$

d) Are you considering laying off or furloughing more workers?

2. a) Do you have any competitors in your field?

b) If YES, how can you rate the competition? i) [Stiff] ii) [Moderate] iii) [Weak]

c) Has corona virus pandemic affected competition? 
d) If YES, How? i) [Increased it] ii) [Reduced it]

e) What do you think would make you outdo your competitors?

3. a) Where did you use to obtain your supplies/raw materials;

i) before pandemic?

ii) after pandemic?

b) Has the input of materials/supplies changed?

c) If YES, How? i) [Changed its source] ii) [It has increased] iii) [It has reduced]

d) How has corona virus pandemic affected the cost of materials/supplies?

i) [It has increased] ii) [No change] iii) [It has reduced]

4. a) Who were your main customers;

i) before the pandemic?

ii) after the pandemic?

b) Has the demand of your products changed?

c) If YES, How? i)[change in customers] ii) [Demand increased] iii) [Demand decreased]

d) How has the corona virus pandemic affected the price of your products?

i) [Price increased] ii) [No change] iii) [Price decreased]

5. What were your average profits per month in Ksh.;

a) before the pandemic; [1-5,000] [6-10,000] [11-15000] [16-20,000] [>20,000]

b) after the pandemic; [1-5,000] [6-10,000] [11-15000] [16-20,000] [>20,000]

6. a) Do you think the government has cushioned your business?

b) If YES, How?

c) Did you have any outstanding business loans before the pandemic?

d) If YES, have you managed to clear them?

e) If NOT YET, when do you anticipate to clear them?

[Within 1yr] [Within 3yrs] [Within 5yrs] [Beyond 5yrs]

f) Is your business insured?

g) Have you engaged in any product promotion/marketing of the business?

7. a) Have you contemplated closing down your business?

b) If YES, is it as a result of corona virus?

8. What would you like to recommend to the government regarding SMEs and the corona virus pandemic 